Elżbieta Potocka

\title{
SPÓR TERYTORIALNY - GŁÓWNĄ PRZESZKODA W NORMALIZACJI STOSUNKÓW ROSYJSKO-JAPOŃSKICH
}

Do końca XX wieku pozostał rok. Czy jednak wystarczy, by Rosja i Japonia pozbyły się obciążeń II wojny światowej? Mimo że od zakończenia amerykańskiej okupacji Japonii i odzyskania przez nią pełnej suwerenności minęło 48 lat, oba państwa nie podpisały traktatu pokojowego. Jego brak jest „rzecza nienormalną", stwierdził w wypowiedzi dla agencji ITAR-TASS 23 sierpnia 1999 r. Maneo Suzuki, zastępca szefa kancelarii rządu, odpowiedzialny za stosunki Japonii z Rosją.

\section{Geneza problemu}

Sytuacja ta powstała w wyniku odmowy podpisania przez Związek Radziecki traktatu pokojowego w San Francisco, w dniu 8 września 1951 r. zaakceptowanego przez innych aliantów. Od chwili rozpoczęcia prac przygotowawczych do jego zawarcia, miał on jednak separatystyczny charakter, gdyż Stany Zjednoczone, jako główne mocarstwo okupacyjne w Japonii zakładały, że Związek Radziecki niekoniecznie musi go podpisać ${ }^{1}$ Władzom w Waszyngtonie chodziło głównie o to, by w traktacie tym nie zatwierdzić zmian, które zaszły na Dalekim Wschodzie po zakończeniu II wojny światowej. Dotyczyło to przede wszystkim nabytków terytorialnych, które w wyniku przyłączenia się do wojny z Japonią uzyskał Zwią- 
zek Radziecki. W tym okresie trwała już „zimna wojna" i amerykańskoradziecka walka o wpływy w rejonie. Stany Zjednoczone nie zamierzały zatem umacniać pozycji swego przeciwnika w rejonie zaostrzających się konfliktów.

W ciągu kilku lat pracy nad traktatem Moskwa domagała się umieszczenia w nim klauzuli o przekazaniu jej suwerennych praw nad południowa częścia Sachalinu i Wyspami Kurylskimi, to jest terytoriami przejętymi przez Związek Radziecki w sierpniu 1945 r, na podstawie tajnego „Porozumienia dotyczącego warunków przystąpienia Związku Radzieckiego do wojny z Japonią" (najcześciej nazywanego porozumieniem Jałtańskim) z 11 lutego 1945 r. ${ }^{2}$. Brak podpisu Związku Radzieckiego na traktacie z San Francisco pozostawił oba kraje formalnie w stanie wojny. Dopiero 3 czerwca 1955 r, politycy z Tokio i Moskwy zasiedli do stołu rokowań, które miały doprowadzić do zawarcia traktatu pokojowego, do czego jednakże nie doszło. Trwające do października 1956 r. rozmowy doprowadziły jedynie do zakończenia formalnego stanu wojny na podstawie tzw. „formuły Adenauera", czyli poprzez podpisanie wspólnej deklaracji o zakończeniu stanu wojny i nawiązaniu stosunków dyplomatycznych ${ }^{3}$. Główna przeszkoda do całkowitej normalizacji stosunków, tj. podpisania traktatu pokojowego, okazały się kwestie terytorialne. Związek Radziecki dążył do uznania jego suwerenności nad przejętymi w 1945 r. terytoriami, zaś Japonia domagała się ich zwrotu.

Postanowienia „Wspólnej deklaracji" z 19 X 1956 r. są jedynie częściowym kompromisem w tym zakresie. Moskwa zgodziła się na zwrot Japonii wysp położonych najbliżej Hokkaido - wyspy Szikotan i grupy pięciu bezludnych wysp Habomai, po zawarciu traktatu pokojowego.

Traktatu pokojowego jednak do tej pory nie podpisano, mimo że wielokrotnie podejmowano takie próby $\mathrm{W}$ latach dziewięćdziesiątych obie strony często mówiły o konieczności jego zawarcia i wielokrotnie zapowiadały doprowadzenie stosunków dwustronnych do pełnej normalizacji. Ostatni raz zapowiedź taka padła w listopadzie 1997 r. w Krasnojarsku podczas spotkania prezydenta Borysa Jelcyna z ówczesnym premierem

\footnotetext{
${ }^{2}$ Tekst porozumienia w: ZD PISM nr 9/10 z $1951 \mathrm{r}$.

${ }^{3}$ Była to nowa formuła w stosunkach międzynarodowych. Pojawiła się dopiero po II wojnie światowej. Umożliwiała faktyczne nawiązanie stosunków między zainteresowanymi stronami, bez rozwiązywania całego szeregu kwestii prawnych wynikających z zakończenia wojny, a rozwiązywanych zwykle przez traktat pokojowy Stąd zakończenie stanu wojny poprzez deklarację dwu stron nie miało charakteru ogólnego (kompleksowego), ponieważ dotyczyło tylko wạskiego kręgu zagadnień, przesuwając w przyszłość problemy najtrudniejsze do rozwiązania, z reguły kwestie terytorialne.
}

Japonii Ryutaru Hashimoto. Strony oświadczyły wówczas, że „podejmą wysiłki w celu podpisania traktatu pokojowego do 2000 roku". Nic nie wskazuje jednak na to, by udało się jeszcze w XX wieku zapowiedź tę zrealizować. Od lat bowiem zasadniczą przeszkodą jest spór terytorialny, dotyczacy kilku wysp. W Japonii określa sie je mianem „terytoriów północnych", bo leżą na północ od zasadniczych wysp japońskich, dla Rosji są to Kuryle Południowe.

\section{Zakres sporu}

W historii sporu zakres japońskich roszczeń ulegał znacznym zmianom. Początkowo terminu ,terytoria północne" używano w sensie szerokim, w odniesieniu do wszystkich terytoriów północnych i północno-wschodnich należacych do Japonii przed II wojna światowa, to znaczy do całego łańcucha Wysp Kurylskich i południowej części Sachalinu. W sierpniu 1956 r. rząd Japonii, chcąc ułatwić proces negocjacji pokojowych z ZSRR, oficjalnie zrzekł się praw do północnej części Wysp Kurylskich i południowej części Sachalinu, sprowadzając swoje roszczenia do minimum. Od tamtej pory termin ten używany jest $\mathrm{w}$ sensie waskim i obejmuje grupe wysp, które wchodziły w skład cesarstwa japońskiego od 1855 r. Jednocześnie jednak zastosowano specyficzną geograficzną interpretacje tego terminu. Otóż grupe tych wysp podzielono na tzw. „Kuryle Południowe", co zdaniem Japonii obejmuje dwie wyspy: Kunaszir i Etorofu, natomiast dwie pozostałe wyspy - Szikotan i grupę wysepek Habomai w Japonii traktuje się jako „geograficzne przedłużenie wyspy Hokkaido", choć nie ma to żadnego naukowego uzasadnienia. W ten sposób termin ,terytoria północne", lub „wyspy północne", nabrał nowego znaczenia i wszedł na stałe do słownictwa politycznego Japończyków. Miał on wyeliminować termin „Wyspy Kurylskie".

Wyspy Kurylskie to łańcuch 32 wysp pochodzenia wulkanicznego, rozciagający sie na długości około 1200 km, od Kamczatki do Hokkaido. Japończycy jak i Rosjanie penetrowali te tereny już od początku XVII wieku, jednakże na mapy naniósł je w roku 1643 holenderski podróżnik i żeglarz Martina de Vriesa i przez ponad 100 lat Holandia zgłaszała do nich swe roszczenia, W XVIII wieku obie strony wykazywały coraz większe zainteresowanie tymi wyspami, jedni wchodzili tam od północy, a drudzy z południa. Podobna sytuacja panowała na Sachalinie (odkrytym przez tego samego Holendra w roku 1643) - Japończycy zjawili się tam pod koniec XVIII w. (w roku 1799), a Rosjanie w początkach XIX (w latach 1804-1806). 
W pierwszej połowie XIX wieku sytuacja w tym rejonie dojrzała do tego, by strony wyraźnie określiły strefy wpływów. 7 lutego 1855 r. zawarto w Szimoda „Umowę o handlu, żegludze i delimitacji granic", która zatwierdziła istniejący stan rzeczy ${ }^{4}$. Ustalono wówczas granicę między Rosją i Japonią. Przebiegała ona pomiędzy wyspami Etorofu (po stronie japońskiej) i Urup (po stronie rosyjskiej), zaś Sachalin pozostał we wspólnym władaniu Rosji i Japonii, bez określania granicy czy podziału na strefy wpływów. Sytuacja ta była kłopotliwa dla obu stron i doprowadzała do konfliktów (w tym i krwawych incydentów). Rozwiązanie tego problemu nabrało szczególnego znaczenia po zawarciu przez Rosję traktatu z Chinami w Aigunie (1858 r.), na mocy którego przyznano jej terytoria na północnym brzegu Amuru, i po traktacie pekińskim (1860 r.) uznającym jej prawa do wschodniego brzegu Ussuri. Rosja utworzyła wtedy wzdłuż brzegów obu tych rzek szereg baz wojskowych, co pozwalało na kontrolowanie całego ruchu na nich. W tej sytuacji posiadanie Sachalinu pozwalało na uzyskanie kontroli także nad ujściami Amuru i Ussuri oraz ruchem przybrzeżnym.

W latach 1862-67 prowadzono negocjacje w celu ustalenia panowania na tej wyspie jednej ze stron. Każda $\mathrm{z}$ nich dążyła bowiem do zachowania wyłącznych tam wpływów, oferując drugiej sprzedaż praw do niej lub wymianę na niektóre Wyspy Kurylskie. W grudniu 1866 r. Rosjanie zaproponowali Japończykom, w zamian za wyłączność praw do Sachalinu, wyspę Urup i trzy sąsiednie na północ od tej wyspy, Japończycy zaś za te same prawa skłonni byli oddać Rosji Etorofu i połowę Kunaszir.

Ich stanowisko z czasem zmieniło się, gdyż Sachalin okazał się mało użyteczny dla osadnictwa japońskiego, a nieprzyjazny klimat i choroby dziesiątkowały przybyszów. Wyspa zasłynęła jako „grób Japończyków". W roku 1869 rzad Japonii zakomunikował gotowość rezygnacji z praw do niej za rekompensatę pieniężną. Wymieniano sumę $2 \mathrm{mln}$ (ówczesnych) jenów. Rosja propozycję tę odrzuciła, ale wyraziła z kolei gotowość do uznania w zamian suwerenności Japonii nad Wyspami Kurylskimi ${ }^{5}$. W rezultacie w 1875 r. strony zawarły nowe porozumienie: „Układ o wymianie Sachalinu na Wyspy Kurylskie ${ }^{6}$. Wówczas to 18 wysp łańcucha północnego stało się częścią Cesarstwa Japońskiego i blokowało rosyjskiej Flocie Pacyfiku wyjście na ocean aż do zajęcia tych wysp przez wojska radzieckie pod koniec II wojny światowej.

\footnotetext{
${ }^{4}$ Tekst traktatu w: J. J. Stephan, The Kudle Islands, dz.cyt., s. 237-238.

${ }^{5}$ Szerzej na ten temat: H. B. Morsa, H, F. McNair, Far Eastern International Relations, Shanghai 1928 , s. $259-261$

${ }^{6}$ Tekst traktatu w: J. J. Stephan, The Kudle Islands, dz.cyt., s. 237-238.
}

Linia graniczna między Rosją a Japonia wytyczona na podstawie układu o wymianie Sachalinu na Wyspy Kurylskie z 1875 roku.

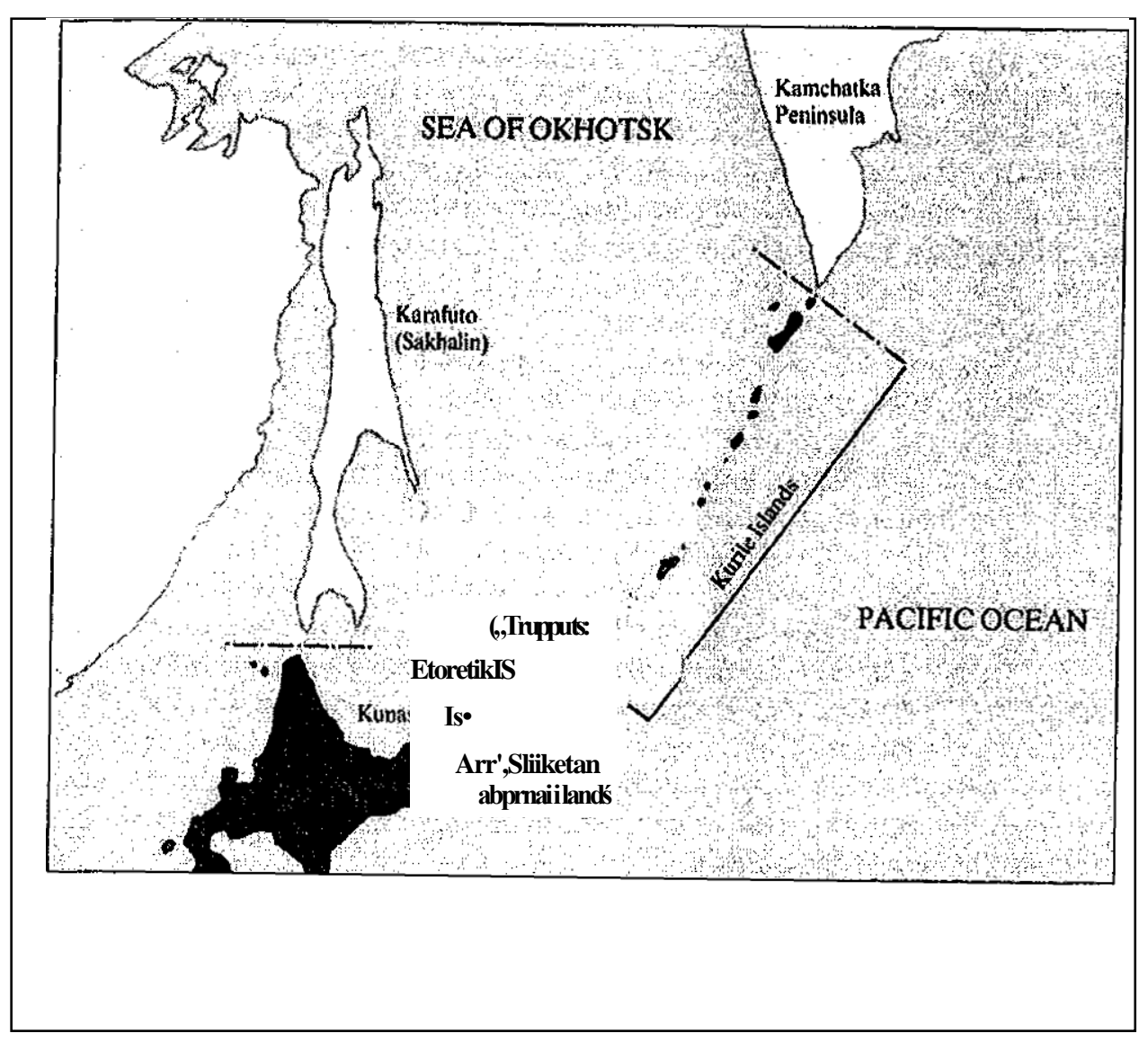

Trzeba wspomnieć, że status Sachalinu ponownie uległ zmianie w wyniku wojny rosyjsko japońskiej 1904-1905. Na mocy Traktatu Pokojowego z Portsmouth południowa jego część została poddana zwierzchności Japonii. Stan taki utrzymywał się aż do 11 sierpnia 1945 r., kiedy to armia radziecka rozpoczęła ofensywę na Sachalinie przeciwko stacjonującym tam jednostkom Armii Kwantuńskiej.

„Wyspy północne", od lat będące przedmiotem sporu, z geograficznego punktu widzenia stanowią południowo-zachodni kraniec Archipelagu Kurylskiego. Łącznie mają one powierzchnię $4996 \mathrm{~km} \mathrm{kw}$. Według danych japońskich do roku 1945 obszar ten zamieszkiwało około 16,5 tys. Japończyków, głównie rybaków, myśliwych i rolników. Przed rozpadem Związku Radzieckiego mieszkało tam około 50 tys. ludzi, w tym około 20 tys. 
wojskowych. Liczbę stacjonujących tam wojsk zredukowano, część ludności opuściła te wyspy dobrowolnie, a część została przymusowo przesiedlona. Obecnie mieszka na nich około 24 tysięcy ludzi, w tym około 10 tysięcy wojskowych ${ }^{7}$. Ludność cywilna to głównie rybacy zajmujący się przetwarzaniem ryb.

Mają one niewielkie znaczenie gospodarcze i w toczącym się sporze jest to kwestia drugorzędna. Znajduja się tam wprawdzie pewne złoża siarki, srebra i złota, ale nie są one eksploatowane. Znacznie większą wartość mają wody otaczające sporne wyspy. żyje w nich wiele gatunków ryb, a tamtejsze łowiska łososia należa do jednych $\mathrm{z}$ najbogatszych $\mathrm{w}$ świecie. Swobodne korzystanie $\mathrm{z}$ tych łowisk, albo raczej utrudnienia, jakie obie strony stwarzały sobie przez pół wieku, prowadziły wielokrotnie do powstawania napiętych sytuacji $\mathrm{w}$ tym rejonie.

Obecnie, przy rozwiniętej technice wojskowej, wyspy te nie mają większego znaczenia strategicznego, jednak do sierpnia 1945 roku znajdowały się tam ważne dla Japonii instalacje wojskowe. Kluczowa role w jej systemie obronnym w tym rejonie miała wyspa Etorofu. Na niej bowiem znajduje się niezamarzający port, z którego w listopadzie 1941 r. flota japońska wypłynęła do ataku na Pearl Harbor.

Dla Rosji ważny jest zarówno niezamarzający pert, jak też i Kanał Kunaszir (Pico Strait), który stanowi jedną $\mathrm{z}$ trzech głównych dróg wyjścia floty rosyjskiej na Pacyfik. Na wyspach Etorofu, Kunaszir i Szikotan znajdują się ponadto rosyjskie bazy nuklearnych łodzi podwodnych oraz instalacje militarne. Rozlokowane są tam również czołgi, samoloty Mig-23, helikoptery i łodzie patrolowe ${ }^{8}$.

Wyspy te są niewątpliwie „bombą polityczną", która wybucha ilekroć któraś ze stron zaczyna mówić o zawarciu traktatu pokojowego. Rozwiązanie problemu terytorialnego w czasach Związku Radzieckiego było traktowane jako instrument polityki zimnowojennej i konfrontacyjnej. Bano się uczynić jakiekolwiek ustępstwo na rzecz Japonii, by nie stworzyć precedensu w tej dziedzinie. Moskwa bowiem miała nieuregulowane spory graniczne $\mathrm{z}$ wieloma sąsiadami, głównie zaś z Chinami. W Japonii problem ten zawsze był traktowany w kategoriach prestiżu i durny narodowej'. Już w grudniu 1945 roku mieszkańcy Hokkaido zaczęli domagać się zwrotu całych Kuryli. Od grudnia 1946 roku wysuwano roszczenia już tylko wobec wysp, które wchodziły w skład Japonii od 1855 r. ${ }^{10}$.

\footnotetext{
7 Dane za: „Komu prinadleżat Jużnyje Kurily?", w: Niezawisimaja Gazieta z 27 X 1998 r.
}

${ }^{8}$ Soviet 8 Troop Leyels Unchanged On N. Isles, w: The Daily Yomiuri z 18 lipca 1990 r.

9 M. Blaker, Japanese Negotiating Style, New York 1977, s. 12.

10 J. J. Stephan, The Kurile Islands, Russo-Japanese Frontier in the Pacific, Oxford 1974, s. 199.
Rząd japoński po raz pierwszy oficjalnie wypowiedział się w tej kwestii w roku 1947. Hitoshi Ashida, ówczesny minister spraw zagranicznych Japonii, obiecał wtedy podjać odpowiednie wysiłki w celu przywrócenia japońskiej suwerenności nad Wyspami Kurylskimi ${ }^{11}$. Następne rządowe oświadczenie dotyczące roszczeń terytorialnych przedstawione zostało na forum parlamentu 22 grudnia 1949 roku. Odmówiono wówczas uznania Porozumienia Jałtańskiego, jako bazy prawnej dla dyspozycji japońskimi terytoriami i przedstawiono roszczenia do tzw. Kuryli Południowych, czyli wysp Etorofu i Kunashir, do wysp stanowiących „przedłużenie Hokkaido" czyli wysp Szikotan i Habomai oraz do południowej części Sachalinu ${ }^{12}$.

Japońskie roszczenia terytorialne nabrały znaczenia po roku 1948, kiedy to wraz ze zmiana kierunku polityki okupacyjnej nastapił wzrost tendencji rewizjonistycznych w tym kraju. Zgłaszano je nie tylko wobec Związku Radzieckiego, ale również wobec Chin i Stanów Zjednoczonych okupujących Okinawę.

Przez lata hasło „Zwrotu terytoriów północnych" było czołowym hasłem wszystkich niemal polityków. Ustanowiono także kilka dat mających przypominać społeczeństwu o tej kwestii. Dzień 7 lutego ogłoszono „Dniem Terytoriów Północnych", a dzień 3 września - „Dniem protestu przeciwko nielegalnej okupacji Terytoriów Północnych przez Związek Radziecki". Obie daty związane sa $\mathrm{z}$ historia tych wysp: 7 lutego 1855 r. podpisano traktat pokojowy w Szimoda, który ustanawiał pierwszą granicę państwową między Rosją i Japonia, a 3 września 1945 r. Rosjanie wkroczyli na ostatnią z wysp, których zwrotu domaga się teraz Japonia i ogłosili „Dzień zwycięstwa nad Japonią". W październiku 1969 r. utworzono „Stowarzyszenie na rzecz powrotu Terytoriów Północnych", popierane przez specjalnie powołany organ rządowy: „Komitet do spraw Terytoriów Północnych". Eisaku Sato obejmując stanowisko premiera oświadczył, że uważa ,problem powrotu Terytoriów Północnych za zadanie numer jeden japońskiej polityki zagranicznej"13. Dodajmy, że premier Sato wykazywał szczególna gorliwość w eksponowaniu tego problemu. Często odwiedzał główny ośrodek ruchu na rzecz powrotu Terytoriów Północnych: najdalej wysuniętą na Hokkaido miejscowość Nemuro, a stamtąd udawał się na przylądek Nosappu, skąd przy dobrej pogodzie widać „odwieczne japońskie terytoria". Jego zdjęcia na tle „historycznych ziem japońskich" obiegły całą

\footnotetext{
${ }^{11}$ The New York Times z 24 stycznia $1.947 \mathrm{r}$.

${ }^{12}$ The New York Times z 23 grudnia $1949 \mathrm{r}$.

${ }^{13}$ The Japan Times z 12 grudnia $1970 \mathrm{r}$.
} 
prasę japońską. W roku 1982 parlament przyjął „Ustawę o podjęciu szczególnych środków w celu odzyskania Terytoriów Północnych".

Wszystkie te akcje wytworzyły przekonanie, że Związek Radziecki nie jest państwem przyjaźnie nastawionym do Japonii. Badania opinii publicznej z 2 października 1989 roku, przeprowadzone przez Biuro Premiera pokazały, że „przyjazne uczucia" wobec Związku Radzieckiego miało tylko 13,2\% respondentów, podczas gdy „złe" aż 81,1\% badanych, a tylko 24,4\% respondentów uznało, że stosunki japońsko-radzieckie są „dobre" ${ }^{14}$

\section{Prawne przesłanki sporu}

15 sierpnia 1945 roku Japonia przyjęła warunki Deklaracji Poczdamskiej, co oznaczało bezwarunkowa kapitulację i zaprzestanie działań wojennych. W tym czasie wojska radzieckie prowadziły działania zbrojne przeciwko Japonii na terytorium Mandżurii, Korei i na Sachalinie. Gdy 9 sierpnia 1945 r. rozpoczynały one ofensywe, miały do pokonania prawie 1,5 miliona żołnierzy. Główny trzon sił japońskich na kontynencie stanowiła ponad milionowa Armia Kwantuńska, stacjonująca na terytorium Mandżurii. Od ataku na Pearl Harbor Amerykanie zabiegali o to, by Rosjanie podjeli działania zbrojne przeciwko tej armili $^{15}$. Jednakże Związek Radziecki dopiero w 1943 r. zgodził się przyłączyć do wojny z Japonią, żądając za tę pomoc, m.in. przekazania mu Wysp Kurylskich.

Zostało to zaakceptowane we wspomnianym tajnym porozumieniu podpisanym przez Roosevelta, Churchilla i Stalina 11 lutego 1945 r. w Jałcie. W trakcie prowadzonych wówczas rozmów nie zastanawiano się nad geograficznym podziałem wysp. Nikt nie dzielił łańcucha Wysp Kurylskich na północne i południowe. Jest jednak bardzo prawdopodobne, że Stalin

mówiąc o przejęciu Wysp Kurylskich - myślał o powrocie do granicy Rosji z Japonią z $1855 \mathrm{r}^{16}{ }^{16}$. Tezę tę zdają się potwierdzać działania wojsk radzieckich na Wyspach, Kurylskich. Inwazję na Szumszu, najdalej na północ położoną wyspe archipelagu Wysp Kurylskich, wojska radzieckie rozpoczęły dopiero 18 sierpnia 1945 roku, tj. w 3 dni po ogłoszeniu przez Japonię kapitulacji, ku całkowitemu zaskoczeniu stacjonujących tam załóg

${ }^{14} 10$ Public Opinion Survey on Diplpmacy by Prime Minister's Office, 1989, Foreign Press Center, Japan.

Więcej na ten temat w moim art. „Polityczne i militarne aspekty przystąpienia Związku Radzieckiego do wojny przeciwko Japonii", w: Dzieje Najnowsze nr 1/2000.

${ }^{16}$ Tekst układu w: J. J. Stephan, The Kunie Islands, dz.cyt., s. 237-238.
18 sierpnia wojska radzieckie dokonaly inwazji na Wyspę Shimushu. Wyspy w pohidniowej części lańcucha będące obecnie przedmiotem sporu zdobywano do 3 września 1945 roku.

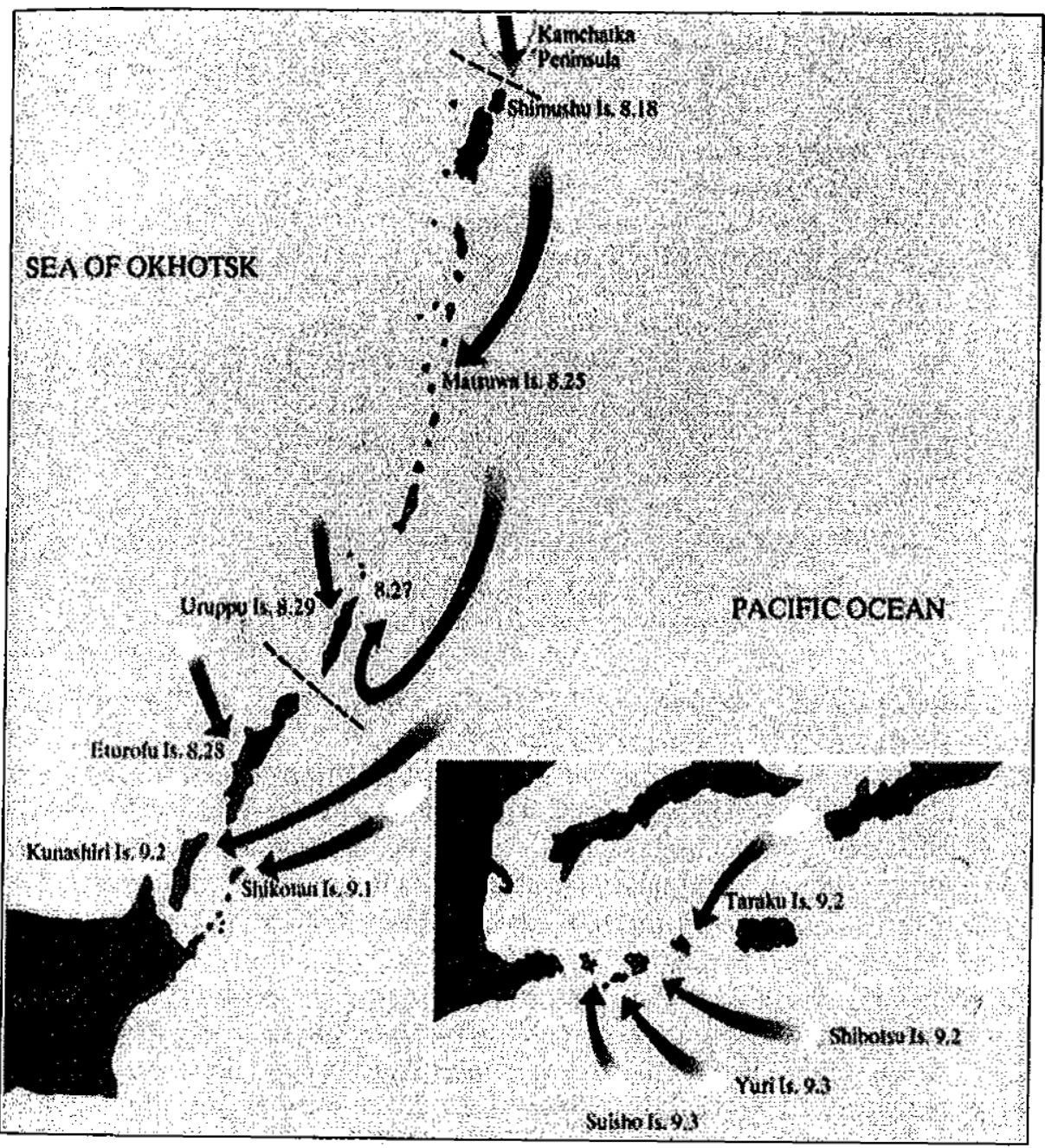

japońskich, nie spodziewających się ataku na własne terytorium. Do 28 sierpnia zajęto wszystkie wyspy północnego łańcucha i zatrzymano się na wyspie Urup. Wojska radzieckie spodziewały się bowiem, że na kolejnej wyspie, to jest Etorofu, znajdować się będą wojska amerykańskie. Kiedy stwierdzono, iż wojsk amerykańskich w tym rejonie nie ma, Rosjanie od 29 sierpnia do 3 września zajęli również wyspy z południowego łańcucha 
Wysp Kurylskich (Etorofu, Kunaszir, Szikotan i grupę wysp Habomai) ${ }^{17}$. Zrobiły to zresztą inne jednostki radzieckie, które specjalnie w tym celu przerzucono z Sachalinu.

2 września 1945 r. wojska amerykańskie rozpoczęły okupację Japonii, która zakończyła, się podpisaniem układu pokojowego w San Francisco. W artykule 2c tego traktatu postanawiano, iż „Japonia zrzeka się wszelkich praw, tytułów i roszczeń do Wysp Kurylskich oraz części Sachalinu i wysp do niego przyległych, nad którymi nabyła suwerenność na podstawie traktatu zawartego w Portsmouth dnia 5 września 1905 roku $^{18}$. Na podstawie tego artykułu zatwierdzono zatem formalnie cesję Wysp Kurylskich i południowej części Sachalinu, bez określenia jednak na rzecz jakiego państwa ona następuje. Sformułowanie dotyczące zaś Kuryli nie precyzowało, jakie wyspy do nich się zalicza. W rezultacie problem wysp sąsiadujących z Hokkaido pozostał otwarty i stał sie zarzewiem napięć między Związkiem Radzieckim (a później Rosją), a Japonią w okresie powojennym.

\section{Pierwszy etap normalizacji stosunków}

Odwilż na linii Moskwa-Tokio stała się możliwa wraz z ogólną poprawą sytuacji międzynarodowej po zakończeniu wojny w Korei i uelastycznieniu polityki zagranicznej Moskwy po śmierci Stalina. Dopiero wówczas Związek Radziecki wystąpił z propozycją unormowania wzajemnych stosunków. Jego koncepcja „normalizacji" sprowadzała się w owym czasie do rozwiązania najpierw wszelkich problemów spornych, by na tej bazie zawrzeć traktat pokojowy, zamykający ostatecznie i formalnie stan wojny między obu państwami. Głównym celem podjętych w czerwcu -1955 r. radzieckojapońskich rokowań pokojowych miało być: dla Moskwy - zatwierdzenie "dalekowschodnich granic", to jest formalne uznanie przez Japonię suwerenności radzieckiej nad terytoriami przyznanymi przez Porozumienie Jałtańskie, których Japonia formalnie zrzekła się w traktacie pokojowym San Francisco w 1951 r. Dla Japonii odzyskanie tych wysp.

${ }^{17}$ The Northern Territorial Issue, Part Twa, Relations with Russia Through 1945, Japan Report, vol. XVI, nr 8, s. 5.

${ }^{18}$ ZD PISM nr 9-10/1951, s. 1697.
Ponieważ Związek Radziecki w latach 1953-1955 wielokrotnie wyrażał gotowość normalizacji stosunków z Japonią, wśród jej przywódców wytworzyło się przekonanie, iż Moskwa uważa ten problem za szczególnie ważny i w zamian za nawiązanie stosunków dyplomatycznych, gotowa będzie pójść na szereg ustępstw, szczególnie w kwestiach terytorialnych.

Radziecko-japońskie rokowania pokojowe 1955-1956 nie spełniły jednak japońskich oczekiwań $\mathrm{w}$ tej kwestii i $\mathrm{z}$ tego powodu nie doszło do pełnej normalizacji stosunków i podpisania traktatu pokojowego. Przystępując do stołu rokowań Japonia liczyła na „zwrot wysp Habomai i Szikotan, geograficznie stanowiących część wyspy Hokkaido", a także zwrot Kunaszir i Etorofu, „które według zapisów historycznych zawsze należały do Japonir ${ }^{19}$. Celem dalszym miało być jednak odzyskanie „całego łańcucha Wysp Kurylskich i południowego Sachalinu, to jest restytucja ,stanu przedwojennego"20.

W pierwszej turze rozmów (od 3 czerwca 1955 do września 1955 roku w Londynie) z postawionych celów Tokio osiagnęło niewiele. Związek Radziecki wyraził ,zgodę na przekazanie Japonii wysp Habomai i Szikotan, po zawarciu traktatu pokojowego, a także pod warunkiem, że ich terytoria nie będą wykorzystywane do celów wojskowych"21.

W drugiej fazie rozmów, toczącej się, z przerwami, od 16 stycznia do 19 października 1956 r. w Moskwie, Japończycy ograniczyli swoje żądania do zwrotu Habomai i Szikotan, a także wysp Etorofu i Kunaszir, usiłując przekonać stronę radziecką, iż te dwie wyspy nie są w istocie częścią Wysp Kurylskich. żądano przy tym zwrotu owych czterech wysp jednocześnie, uzależniając od tego podpisanie traktatu pokojowego.

Takie stawianie sprawy nie przyniosło postępu w rozwiązaniu tej kwestii. Szef japońskiej delegacji, minister spraw zagranicznych Mamoru Szigemitsu, uznajac, że upór ze strony japońskiej jest przeszkoda w doprowadzeniu rokowań do końca, 11 sierpnia 1956 roku oświadczył, że „trzeba skończyć bezowocną dyskusję nad problemem terytorialnym i podpisać traktat pokojowy na proponowanych przez Związek Radziecki warunkach" 22

${ }^{19}$ Fumio Ikematsu, Japanese-Sovieł Relations, Contemporary Japan 1957, vol. XXIV, nr 10-12, s. 561.

Asahi z 27 maja 1955 r.

${ }^{21}$ S. Newskij, Sowietsko-japonskije otnoszenia, Mieżdunarodnaja Żiżń, nr 4/1956, s. 39.

${ }^{22}$ D. C. Hellmann, Japanese Foreingn Policy and Domestic Politics. The Peace Agreement with the Soviet IJnion. Berkeley, Los Angeles and New York 1969, s. 37. 


\section{Wpływ „Czynnika amerykańskiego" na proces negocjacji}

Kompromisowego stanowiska w tej kwestii jednak nie wypracowano. Duży wpływ na przebieg rokowań miała opinia Stanów Zjednoczonych, które nie były zainteresowane uznaniem status quo na Dalekim Wschodzie. Nie chciały one bowiem dopuścić, by Japonia zaakceptowała suwerenność ZSRR nad terytoriami przyznanymi mu przez Porozumienie Jałtańskie, a co za tym idzie uznała to porozumienie za podstawę prawną przynależności Kuryli do Związku Radzieckiego. Stany Zjednoczone - na nowym etapie konfrontacji z Moskwą podważały bowiem definitywny charakter tego porozumienia, uznając je jedynie za deklarację politycznych celów aliantów. W rezultacie kwestię przynależności Południowego Sachalinu oraz Wysp Kurylskich traktowano jako otwartą, zaś zatwierdzenie terytorialnych nabytków radzieckich powinno, ich zdaniem, nastąpić na konferencji pokojowej ${ }^{23}$.

Waszyngton uciekł się nawet do szantażu politycznego wobec Japonii. 19 sierpnia 1956 r. ówczesny sekretarz stanu J. F. Dulles zagroził, że w przypadku podpisania przez Japonię układu pokojowego ze Związkiem Radzieckim i zrzeczenia się w nim wysp Etorofu i Kunaszir, a tym samym uznania ich za część terytorium radzieckiego, Stany Zjednoczone poproszą ją o potwierdzenie, że Okinawa (zamieszkiwana w owym czasie przez ponad milion Japończyków) jest terytorium amerykańskim²4. Ostatecznie 19 października 1956 r., zamiast układu pokojowego, podpisano tylko deklarację o zakończeniu stanu wojny i nawiązaniu stosunków dyplomatycznych. W punkcie 9 „Wspólnej deklaracji" zawarto postanowienie o zwrocie tylko dwu wysp Habomai i Szikotan, ale po zawarciu traktatu pokojowego ${ }^{25}$.

Warto zwrócić uwagę na pewien dość istotny szczegół z końcowego etapu dyskusji nad nią. Związek Radziecki gotów był do umieszczenia w tekście komunikatu końcowego ogólnego sformułowania „problem terytorialny" jako bazy wyjściowej do przyszłych rokowaniach. Strona japońska nalegała natomiast, by $\mathrm{w}$ treści komunikatu umieścić postanowienie o przekazaniu wysp Habomai i Szikotan. Moskwa wyraziła zgodę na umieszczenie w dokumencie pożądanego przez Tokio sformułowania zamiast preferowanego przez nią o charakterze ogólnym. Stanowisko obu państw w tej

\footnotetext{
${ }^{23}$ ZD PISM nr 9-10/1951, s. 1578, także Department of State Bulletin, Jan. 8. 1951, s. 66.

${ }^{24}$ New York Times z 29 sierpnia 1956 r.

${ }^{25}$ Prawda z 20 października 1956 r.
}

kwestii było odzwierciedleniem ich taktyki w rozwiązywaniu tego problemu. Moskwa proponowała sformułowanie ogólne, nie chcąc wiązać się żadnymi konkretnymi zobowiązaniami. Jednakże ewentualne ustepstwa chciała ograniczyć tylko do wysp Habomai i Szikotan, i dlatego zaakceptowała umieszczenie w.tekście „Wspólnej deklaracji" zapisu o ich przekazaniu Japonii. Zostało to uznane przez rząd radziecki za „ostateczne rozwiązanie kwestii terytorialnej", co podkreślono w liście premiera Bułganina do premiera Hotoyamy. Premier radziecki oświadczył tam: „,daliśmy Japonii możliwość wyboru i żadne inne ustępstwa $\mathrm{w}$ tym przedmiocie nie będą poczynione ${ }^{26}$.

Zdaniem strony radzieckiej Japonia dokonała wyboru rozwiązania jej roszczeń terytorialnych, rezygnując $\mathrm{z}$ umieszczenia w deklaracji znacznie szerszego sformułowania ,problem terytorialny" na rzecz zawarcia w niej zobowiązania do przekazania wysp Habomai i Szikotan po zawarciu traktatu pokojowego. Zupełnie odmiennie interpretowała postanowienia punktu 9 strona japońska. Premier Hotoyama zdając relację na forum parlamentu z tych negocjacji stwierdził, że zarówno Japonia jak i Związek Radziecki rozumieją, iż rozmowy dotyczące „problemu terytorialnego" będą kontynuowane i dotyczyć one będą także wysp Etorofu i Kunaszir.

Rozmów pokojowych nie podjęto jednak przez następne kilkanaście lat, gdyż żaden $\mathrm{z}$ partnerów nie był $\mathrm{w}$ istocie zainteresowany ich rozpoczęciem. Negatywny wpływ na postawę obu stron wywierały stosunki Japonii ze Stanami Zjednoczonymi. 19 stycznia 1960 roku oba te państwa podpisały układ o wzajemnej współpracy i bezpieczeństwie ${ }^{27}$. Artykuł VI tego układu przewidywał pozostawienie na terytorium Japonii ,lądowych, powietrznych i morskich sił zbrojnych" Stanów Zjednoczonych, z możliwością korzystania przez nie $\mathrm{z}$ wszelkich udogodnień. Wywołało to zaniepokojenie Związku Radzieckiego, a także Chin. Oba państwa uznały sytuację wytworzoną na Dalekim Wschodzie za „zagrożenie dla pokoju i bezpieczeństwa", tym bardziej, że w układzie nie został dokładnie sprecyzowany zakres terytorialny tego porozumienia. $\mathrm{Z}$ oficjalnych wypowiedzi japońskich i amerykańskich, jeszcze przed podpisaniem układu, wynikało, że miał on obejmować swoim zasięgiem nie tylko terytorium Japonii lecz i „Dalekiego Wschodu".

${ }^{26}$ Y. C. Kim, Japanese-Soviet Relations: Interaction of Politics, Economics and National Security, London 1974, s. 25.

${ }^{27}$ Tekst układu w: UN Treaty Series, vol. 373, s. 179-205, tekst polski w: ZD PISM nr 1/1960, s. $48-61$. 
Mówiąc na forum parlamentu 16 listopada 1959 r. o zakresie jego działania, minister spraw zagranicznych Japonii Fujiyama stwierdził, że termin „Daleki Wschód" obok samej Japonii obejmuje także Koreę, Filipiny, wybrzeże Chin oraz Nadmorski Kraj Związku Radzieckiego. Przy czym wyjaśniał, że nie tylko wybrzeże Chin i radzieckiego Kraju Nadmorskiego mogą być ewentualnym terenem działania japońsko-amerykańskiego układu wojskowego, lecz także i głębiej położone tereny obu państw ${ }^{28}$. W wyniku tak rozumianego zakresu terminu „Daleki Wschód", na mapach przeznaczonych dla celów wojskowych, w skład „obszaru obronnego" Japonii zaliczano nie tylko cztery główne wyspy japońskie, ale także „terytoria północne" (to jest cztery sporne wyspy), a ponadto część terytorium ChRL, Kraj Nadmorski, część Syberii, Sachalin, Kamczatkę i Wyspy Kurylskie $^{29}$.

Jeszcze dalej w interpretacji terminu „Daleki Wschód" szły Stany Zjednoczone. Christian A. Herter, sekretarz stanu USA, na forum senackiej Komisji Spraw Zagranicznych 7 czerwca 1960 r. oświadczył, że termin „Daleki Wschód", występujący w amerykańsko-japońskim układzie wojskowym, obejmuje także terytoria Związku Radzieckiego, ChRL i innych państw tego regionu" ${ }^{30}$.

Amerykańsko-japoński układ o bezpieczeństwie, wymierzony przeciwko Związkowi Radzieckiemu, a poniekąd i Chinom, spowodował wzrost napięcia w stosunkach radziecko-japońskich, co całkowicie wykluczyło możliwość podjęcia przez obie strony rokowań dotyczących zawarcia traktatu pokojowego. Bezpośrednim następstwem pogorszenia atmosfery na przełomie lat pięćdziesiątych i sześćdziesiątych była zmiana stanowiska radzieckiego w sprawie przekazania Japonii wysp Habomai i Szikotan. Moskwa uznała bowiem, iż „mogłyby one zostać wykorzystane przez obce wojska" i oświadczyła, że wyspy te ,zostaną przekazane Japonii jedynie pod warunkiem wycofania $z$ tego kraju obcych wojsk i podpisania traktatu pokojowego" ${ }^{31}$. Napięcie w stosunkach radziecko-japońskich wzrosło jeszcze w wyniku naruszania terytorium radzieckiego przez loty zwiadowcze amerykańskich samolotów typu Lockheed U-2. Związek Radziecki zadeklarował wówczas, że „w celu zapewnienia bezpieczeństwa narodu radzieckiego będzie zmuszony podjąć odpowiednie kroki, włącznie z ude-

${ }^{28}$ Asahi Shimbun z 18 listopada 1959 r. oraz G. P Żukow, W intieresach Japonii niejtralitet, Moskwa 1960, s. 34 i 57.

${ }^{29}$ Prawda z 14 kwietnia 1960, takie Comtemporary Japan [dalej: C. J.] 1960,

vol. XXVI, nr 3.

${ }^{30}$ C. J. 1960, vol. XXVI, nr 4, D. M. s. 798, takie ZD PISM nr 6/1960, s. 1034

${ }^{31}$ ZD PISM, nr 1/1960, s. 68. rzeniem w te bazy, które będą wykorzystywane do przeprowadzania takich lotów" ${ }^{32}$.

\section{Drugi etap normalizacji stosunków radziecko-japońskich}

Drugi etap normalizacji stosunków radziecko-japońskich nastąpił dopiero po szesnastu latach od nawiązania stosunków dyplomatycznych. Zmiany jakie zachodziły w Azji Wschodniej w końcu lat sześćdziesiątych i na początku siedemdziesiątych, zmusiły Japonię do rewizji dotychczasowej polityki. Zaostrzanie się sprzeczności w sojuszu japońsko-amerykańskim, klęska militarna i polityczna USA w Wietnamie oraz zbliżenie amerykańskochińskie, przy otwartej wrogości Pekinu i Moskwy; sprawiły, że polityka zagraniczna Japonii po 1971 r. nabrała charakteru „dyplomacji wielokierunkowej". Jej efektem był aktywny rozwój kontaktów Japonii z krajami Azji Południowa Wschodniej, Europy Zachodniej, a także z Chinami i Związkiem Radzieckim.

Oficjalna wizyta Andreja Gromyki, ministra spraw zagranicznych Związku Radzieckiego, w Tokio w styczniu 1972 r. odbywała się w sprzyjającej atmosferze. Najważniejszym jej efektem w sferze stosunków politycznych była zapowiedź corocznych konsultacji na szczeblu Ministerstw Spraw Zagranicznych oraz zapowiedź wznowienia, jeszcze w 1972 r., japońsko-radzieckich rokowań dotyczących zawarcia traktatu pokojowego ${ }^{33}$.

Gotowość Moskwy do rozpoczęcia rokowań pokojowych uznana została przez stronę japońską jako przejaw nowego jej podejścia do problemu terytorialnego. Sądzono tak, między innymi, dlatego, że podczas tej wizyty Gromyko nie odwoływał się już do znanego argumentu, że ,problem zosta rozwiązany" ${ }^{34}$, a porozumienie o podjęciu rokowań pokojowych zdawało się wskazywać, że obie strony skłonne są do poszukiwania jakiegoś kompromisowego rozwiązania.

W lutym 1972 r. prezydent Richard Nixon złożył oficjalną wizytę w Pekinie i uznał ChRL za jedyne państwo chińskie. Zbliżenie amerykańskochińskie zupełnie zaskoczyło Japonię. Obawiała się ona, że może to doprowadzić do wyparcia jej z rynku chińskiego, szczególnie w zakresie dostaw maszyn i urządzeń, a dotychczas była ona w tej dziedzinie głównym partnerem handlowym Chin. Japończycy obawiali się też, by nor-

${ }^{32}$ C. J., vol. XXVI, nr 4/1960, D. M., s. 795-802, takie Prawda z 21 maja 1960.

${ }^{33}$ Prawda z 29 stycznia 1972 r, także Japan Quartetly. vol. XIX, nr 2/1972, s. 243.

${ }^{34}$ Y. C. Kim, Japanese-Sowiet Relations, dz.cyt., s. 39. 
malizacja stosunków między Stanami Zjednoczonymi, a Chinami nie doprowadziła do zmiany istniejących sojuszów politycznych w Azji i zmiany uprzywilejowanej roli Japonii. Mogłoby to bowiem oznaczać powrót do dawnej, jeszcze z okresu wojny, koncepcji politycznej, zakładającej, że najpotężniejszym sojusznikiem USA w tej części świata, państwem mającym stanowić klucz do amerykańskiej polityki w Azji po wojnie, będą Chiny

Japończycy ze szczególną uwagą obserwowali zbliżenie amerykańsko-chińskie, ale też radziecko-amerykańskie spotkanie na szczycie (szok Nixona) w maju 1972 r. Oba te procesy analizowano i przewidywano ich wpływ na pozycję Japonii w rejonie.

Częściowa normalizacja stosunków japońsko-chińskich, we wrześniu 1972 r., spowodowała, że nie doszło do zapowiadanego na ten miesiąc spotkania ministrów spraw zagranicznych Japonii i Związku Radzieckiego (Ohira-Gromyko), a ich październikowe spotkanie odbywało się w dość chłodnej atmosferze ${ }^{36}$. W jego trakcie nie osiagnięto żadnego postepu w sprawie traktatu pokojowego, ponieważ prowadzone rozmowy zdominowała dyskusja nad ,problemem terytorialnym". Tokio domagało się, tak jak w poprzednich rozmowach, zwrotu „terytoriów północnych", a Moskwa określiła te żądania jako „bezpodstawne" i potwierdziła jedynie gotowość zwrotu Habomai i Szikotan ${ }^{37}$

Pozycje rzadu Japonii w rozmowach z Moskwa umocniło wprawdzie oddanie jej Okinawy, okupowanej od 1945r. przez USA, jednakże wielu ekspertów i biznesmenów japońskich uważało, że ich rząd powinien wykazać więcej realizmu i zrezygnować z roszczeń do wysp Kunaszir oraz Etorofu, dla osiągnięcia korzyści politycznych i gospodarczych, wynikających z poprawy stosunków ze Związkiem Radzieckim ${ }^{38}$. W tym czasie rozwijała się, np. korzystnie współpraca w zagospodarowywaniu Syberii i radzieckiego Dalekiego Wschodu ${ }^{39}$. Kryzys paliwowy stał się dodatkowym czynnikiem, powodującym wzrost zainteresowania Japonii współpracą $\mathrm{z}$ bliskim sasiadem oraz jego zasobami.

Poprawę klimatu w stosunkach radziecko-japońskich potwierdziła wizyta premiera Kakuei Tanaki i ministra spraw zagranicznych Ohiry w Moskwie w październiku 1973 roku. Poruszenie w trakcie rozmów kwe-

${ }^{3}$ Szerzej na ten temat m.in. w: H. M. Vinacke, The United States in the Far East 1945

1951, London 1952, s. 48-52; Sumner Welles, Seven Major Decisions, London 1951.

${ }^{36}$ Japan and New Asia, s. 35

${ }^{37}$ Prawda z 25 października $1972 \mathrm{n}$

${ }^{38}$ J. J. Stephan, Thw Kudle lslands, dz. cyt., s. 209.

39 J. J. Stephan, Thw Kudle lslands, dz. cyt., s. 209. dipłomaticzeskich otnoszenij, Moskwa 1971, s. 104-130, także R. N. North, The Soviet Far East: New Center of Ałtention in the USSR, Pacific Affairs, vol. 51, nr 2/1978 stii traktatu pokojowego nie budziło już tak wielkiego sprzeciwu ze strony radzieckiej. Premier Tanaka usiłował przekonać Breżniewa, że problem „terytoriów północnych" stanowi główną przeszkodę w stosunkach dwustronnych i nalegał na jego rozwiązanie. Związek Radziecki wówczas nie był jednak jeszcze gotów do dyskusji tego problemu, ale nie chciał też, w sytuacji zbliżenia Chin z USA i Japonia, okazywać wobec tej ostatniej wrogiej postawy. Efektem było stwierdzenie we wspólnym komunikacie, że rozmowy na temat „nierozwiązanych problemów pozostałych z II wojny światowej" zostaną podjęte „w odpowiednim czasie w 1974 roku" $^{40}$.

Strona japońska każdą z rozmów na temat traktatu pokojowego łączyła z problemem terytorialnym podkreślając, że jest to ,główne nierozwiązane zagadnienie w stosunkach między obu państwami". W czasie spotkania Breżniew-Tanaka, strona radziecka poszła na znaczące ustępstwa w tej kwestii, godząc się na umieszczenie we wspólnym komunikacie stwierdzenia, że „uregulowanie nierozwiązanych problemów pochodzących z okresu II wojny światowej i zawarcie układu pokojowego, wniosą istotny wkład w ustanowienie dobrosąsiedzkich i przyjacielskich stosunków między obu krajami" ${ }^{41}$. W istocie strona radziecka potwierdziła istnienie „problemu terytorialnego" i chęć jego rozwiązania. Do 1973 r. dyskusje nad tym problemem nigdy nie znajdowały odbicia w komunikatach koń cowych, gdyż w interpretacji Moskwy został on już ostatecznie rozwiązany. Zatem sformułowania użyte w komunikacie (,nierozwiązane problemy", co strona japońska jednoznacznie rozumiała jako „problem terytorialny") świadczyły o koncyliacyjnej postawie Moskwy

\section{Wpływ „Czynnika chińskiego" na proces negocjacji}

W 1974 r. zapowiadanych rozmów na temat traktatu pokojowego jednak nie podjęto. Niewątpliwy wpływ na ten stan rzeczy miały prowadzone jesienia tego roku japońsko-chińskie rokowania pokojowe, których charakter w Moskwie uznano za „antyradziecki". Polityka „równego dystansu”, którą Japonia stosowała wobec Moskwy i Pekinu, polegającą na uznaniu równorzędności stosunków $\mathrm{z}$ obu tymi partnerami, uległa wyraźnej zmianie, gdy zdecydowała się ona podpisać traktat pokojowy z Chinami. Chiny nalegały bowiem na włączenie do tego traktatu „klauzuli anty-he-

${ }^{40}$ Prawda z 11 października $1973 \mathrm{r}$.

${ }^{41}$ j.w. 
gemonistycznej", a walkę z dążeniami do uzyskania hegemonii w Azji Wschodniej przez jakieś państwo Pekin niedwuznacznie kierował przeciwko Moskwie. Deng Xiaoping dodał jeszcze, Że klauzula ta ma „umocnić pozycję Japonii" w jej terytorialnych roszczeniach wobec Związku Radzieckiego ${ }^{42}$. Chiny twierdziły, że jednym $\mathrm{z}$ przejawów radzieckiego hegemonizmu jest okupacja Wysp Kurylskich ${ }^{43}$.

Chiny już od 1964 r. popierały japońskie roszczenia terytorialne, gdyż same zgłaszały podobne pretensje wobec Moskwy ${ }^{44}$. Po chińsko-radzieckim konflikcie granicznym na rzece Ussuri w 1969 r. jeszcze dobitniej popierano żądania Japonii, a w 1972 r. kierownictwo chińskie uznało japoński „problem terytorialny" za jeden z ważniejszych punktów zbliżenia z tym krajem. 21 stycznia 1972 r., na dwa dni przed rozpoczęciem rozmów japońsko-chińskich, premier Zhou Enlai (Czou En-laj) wyraził, np. pełne poparcie dla japońskich żądań zwrotu wysp Habomai, Szikotan, Kunaszir i Etorofu. W 1973 r. mówił o „naturalnym prawie" Japonii nie tylko do wymienionych wyżej wysp, ale także do całego archipelagu Wysp Kurylskich ${ }^{45}$

Takie stanowisko chińskie dawało stronie japońskiej dodatkowe atuty w rozmowach politycznych z Moskwą, choć nie było najmniejszych wątpliwości, że miały one charakter koniunkturalny i wynikały $z$ ogólnego stanu napięcia w stosunkach chińsko-radzieckich.

Wszystko to spowodowało wyraźne ochłodzenie w stosunkach radzieckojapońskich i sprawiło, że cztery kolejne spotkania ministrów spraw zagranicznych obu państw w latach 1974-1978 kończyły się fiaskiem. Ciążyła bowiem nad nimi atmosfera japońsko-chińskich rokowań pokojowych zacieśnianie przez oba kraje współpracy. Ponadto popieranie przez Chiny japońskich roszczeń terytorialnych powodowało bardziej ofensywną, czy jak określała to Moskwa - agresywną postawę strony japońskiej w kontaktach z Rosjanami.

Dało się zauważyć, że uciekano się do metod politycznego nacisku na Moskwę, usiłując wykorzystać czynnik chiński dla „zmiękczenia" jej postawy.

$\mathrm{W}$ trakcie wieloletnich rokowań z Moskwa Japonia nie godziła się na wypracowanie żadnego kompromisu w kwestii terytorialnej. Wychodziła

\footnotetext{
${ }^{42}$ The Washington Post z 25 kwietnia 1975 r.

${ }^{43}$ Le Monde z 8 maja 1978 r.

${ }^{44}$ W 1964 r. Mao popierał japońskie roszczenia terytorialne twierdząc, że „Kuryle powinny wrócić do Japonii", bo „Rosja już i tak zagarnęła za dużo terytoriów". Chiny zgłaszały pretensje m.in. do obszarów nad Amurem, Kraju Nadmorskim, Sachalinu, części Kazachpretensje m. ́n. do obszarow nad Amurem, Kraju Nadmorskim, Sachalinu, częsci Kaza ${ }_{45}$ Azsi Srodkowej - Asahi Shimbun z 29 stycznia 1973 r.
}

ona z założenie, iż japońskie stanowisko jest a priori słuszne, zatem założone cele sa możliwe do osiagnięcia. Japończycy zakładali, że w kwestii terytorialnej powinni osiagnać ,wszystko albo nic". Przy czym, od rozwiązania tej kwestii, uzależniali wszelki postęp w stosunkach politycznych i gospodarczych ze Związkiem Radzieckim.

W styczniu 1976 r. wizytę w Tokio złożył ponownie minister Gromyko. Jak już powiedziano wyżej, ciążyła nad nią atmosfera japońsko-chińskiego zbliżenia, która dodawała stronie japońskiej pewności. Premier Miki w czasie rozmów z ministrem Gromyko oświadczył, iż uzależnia podpisanie traktatu pokojowego ze Związkiem Radzieckim od zwrotu Japonii „terytoriów północnych". Dziennik The Yomiuri Shimbun z 6 stycznia 1976 r., powołując się na opinię japońskiego MSZ, pisał, iż „Japonia może odmówić podpisania wspólnego komunikatu, jeśli strona radziecka nie wyrazi zgody na stwierdzenie na piśmie, że wśród problemów pozostajacych do rozwiązania przed podpisaniem traktatu pokojowego znajdują się zagadnienia terytorialne". Minister spraw zagranicznych Miyazawa stwierdził natomiast, że „w tej dziedzinie dojdzie do jakichś postępów dopiero wówczas, gdy Rosjanie uznają, że rozwiązanie tego problemu leży $\mathrm{w}$ ich interesie" ${ }^{46}$.

Skutek przyjętej przez Japonię postawy był odwrotny do zamierzonego: nastapiło bowiem poważne ochłodzenie, jeśli nie zamrożenie, wzajemnych stosunków i pogłębienie rozbieżności w kwestii terytorialnej. Na pogorszenie tych stosunków wpłynęły dodatkowo dwa wydarzenia z 1976 r. 6 września na Hokkaido przymusowo wylądował radziecki samolot wojskowy MIG-25. Został on przejęty przez Amerykanów, dla których była to wyjątkowa okazja do zapoznania się z radziecką technologią wojskową ${ }^{47}$. Ponadto zaś 11 września tego roku minister spraw zagranicznych Japonii odbył rejs dookoła „terytoriów północnych" na pokładzie łodzi patrolowej ${ }^{48}$. Akt ten z jednej strony miał podkreślić przynależność tych wysp do Japonii, z drugiej zaś wyrażać jej niezadowolenie z powodu sztywnej postawy radzieckiej wobec japońskich roszczeń terytorialnych ${ }^{49}$. Moskwa potraktowała te ,inspekcje" jako akt wrogi, wymierzony przeciwko jej interesom. Spowodowało to w efekcie odwołanie przez Moskwę wizyty japoń-

${ }^{46}$ Asahi Shimbun z 2 stycznia $1976 \mathrm{r}$.

47 Keesing's Contemporary Archive (KCA] 1976, s. 27896, KCA 1977, s. 28166 Także S. Awanohara, Jet-lag Snarls Tokyo's Links with Moscow, Far Eastern Economic Review z 17 października $1976 \mathrm{r}$.

${ }^{48}$ Japan Quarterly No. 1/1977, Tokyo-Moscow Ties Tenese, s. 6.

49 j.w. 
skiego ministra spraw zagranicznych Sunao Sonody, jaką ten miał złożyć w 1977 r.

Doszła ona do skutku dopiero w styczniu 1978 r. Głównym jej tematem miał być problem zawarcia traktatu pokojowego. W Japonii ciągle jeszcze usiłowano przedstawiać tę wizytę w kontekście polityki „równego dystansu wobec Moskwy i Pekinu". Była ona jednak ostatnią, jaką można by jeszcze uznać za mieszczącą się w tych kategoriach. Jej przebieg, jak i założenia strony japońskiej, niemal z góry zakładały brak wyników. Japonia ciągle liczyła na wykorzystanie „karty chińskiej" w dyskusjach nad problemem terytorialnym.

Podczas rozmów politycznych w Moskwie, minister Sonoda wyraził opinię, iż w celu ustanowienia prawdziwie przyjacielskich stosunków między Japonią i Związkiem Radzieckim konieczny jest zwrot Japonii wszystkich czterech „wysp północnych" ${ }^{50}$. Przy czym strona japońska nalegała, by podstawę do dyskusji nad tym problemem stanowił wspólny komunikat radziecko-japoński z 10 października 1973 r., który wspomniał o „nierozwiązanych problemach z czasów wojny". W rezultacie nie osiągnięto Żadnego postępu, a wszystkie te czynniki spowodowały, że Związek Radziecki uznał sytuacje na Dalekim Wschodzie za mało stabilna i zadeklarował, Że dokonanie jakichkolwiek zmian jego obecnych granic jest niemożliwe. Konsekwencją tego stanowiska było twierdzenie, iż między Japonią a ZSRR nie ma żadnego ,problemu terytorialnego" ${ }^{51}$.

Moskwa obawiała się jednak skutków zbliżenia japońsko-chińskiego. Nie mogąc doprowadzić do zawarcia traktatu pokojowego z Japonią, zaproponowała „układ o przyjaźni i stosunkach dobrosąsiedzkich". Propozycję taką przedstawiono trzy razy: 13 lutego 1975 r., następnie w styczniu 1976 r. podczas wizyty w Tokio ministra Gromyki, i w styczniu 1978 r. ministrowi Synodzie w Moskwie. Zdaniem strony radzieckiej, układ taki podniósłby stan stosunków politycznych między obu krajami na wyższy poziom, nie zastępując wszakże traktatu pokojowego, lecz jedynie przesuwając go w czasie ${ }^{52}$. Moskwa przykładała tak wielką wagę do tego substytutu traktatu pokojowego, iż w styczniu 1976 r. minister Gromyko podczas wizyty w Tokio wyraził wręcz gotowość przekazanie Japonii wysp Habomai i Szikotan po podpisaniu wyżej wspomnianego układu ${ }^{53}$. Z japońskiego punktu widzenia propozycja ta była jednak nie do przyjęcia:

Asian Recorder, January 12-18, 1978, s. 14169

${ }^{51}$ Wywiad ambasadora ZSRR w Japonii Dimitra S. Polańskiego dla dziennika The Mainichi Shimbun z 11 grudnia $1978 \mathrm{r}$.

${ }^{52}$ Prawda z 3 marca 1978 r. i Izwiestia z 22 lutego 1978 r.

${ }^{3}$ KCA 1976, s. 27599. zgoda na zawarcie jakiegokolwiek układu o przyjaźni ze Związkiem Radzieckim spowodowałaby bowiem, że uznałby on „,problem terytorialny" za ostatecznie rozwiązany, a odzyskanie wszystkich czterech wysp Japonia uważała za warunek sine qua non całkowitej normalizacji stosunków dwustronnych ${ }^{54}$

Minister Miyazawa stwierdził, że ,z prawnego punktu widzenia stan pokoju między Japonią a Związkiem Radzieckim nie został przywrócony, zatem nie byłoby słuszne zawarcie układu o przyjaźni i stosunkach dobrosąsiedzkich, zanim nie zostanie zawarty traktat pokojowy" ${ }^{\prime 5}$. Strona japońska podkreślała, że tylko po zwrocie wszystkich czterech wysp objętych terminem ,terytoria północne", będzie gotowa zawrzeć taki układ ${ }^{56}$.

Trudności w dojściu do porozumienia z Japonią spowodowały podjęcie przez Moskwę jednostronnych decyzji umacniających jej panowanie nad Kurylami Południowymi. W kwietniu 1976 r. Związek Radziecki wprowadził szereg utrudnień dla Japończyków, odwiedzających groby przodków na terytoriach spornych: przede wszystkim konieczność posiadania radzieckiej wizy. 1 marca 1977 r. włączono zaś wody wokół spornych wysp do radzieckiej 200-milowej strefy ekonomicznej ${ }^{57}$.

Od 1977 r. Moskwa zaczęła wręcz twierdzić, że między obu państwami w ogóle nie ma problemów terytorialnych. Najpełniej to usztywnione stanowisko przedstawił D. S. Poliański, ambasador radziecki w Tokio, w wywiadzie dla dziennika The Mainichi Shimbun (11 grudnia 1978 r). Stwierdził on, że ,traktat pokojowy z San Francisco wyraźnie podkreśla, iż Japonia zrezygnowała z żądań zwrotu Wysp Kurylskich. Ponadto tekst traktatu nie przeprowadza podziału łańcucha wysp na południowe i północne Kuryle. Zatem między Japonia i Związkiem Radzieckim nie ma problemu terytorialnego i Związek Radziecki nie odda żadnej części swojego terytorium innemu państwu".

12 sierpnia 1978 r., Japonia podpisała „Traktat pokoju i przyjaźni" z Chinami, łącznie z klauzulą anty-hegemonistyczną, wymierzoną przeciwko Związkowi Radzieckiemu. W art. 2 tego traktatu czytamy: „obaj sygnatariusze nie będą dążyć do zdobycia hegemonii w rejonie Azji-Pacyfi$\mathrm{ku}$, jak też w jakimkolwiek innym rejonie świata. Wyrażają także swój sprzeciw wobec podejmowania przez jakiekolwiek kraj lub grupe krajów prób ustanowienia takiej hegemonii". Złagodzić wymowę tego stwierdze-

${ }^{54}$ The Japan Times z 14 lutego $1975 \mathrm{r}$.

${ }_{56}^{55}$ The Foreign Policy of Modern Japan, ed. by R.A.Scalapino, Los Angeles 1971, s. 170.

${ }_{56}$ KCA 1976, s. 26599.

57 P L Falkenheim Some Determing Factors in Sowiet-Japanese Relations, Pacific Affairs, vol. $50, \mathrm{nr} 4 / 1977-78$, s. 605 . 
nia miał artykuł 4, w którym deklarowano, że ,traktat ten nie będzie wpływał na stosunki jego sygnatariuszy z krajami trzecimi" ${ }^{58}$

Podpisanie w Pekinie tego traktatu zakończyło w polityce zagranicznej Japonii etap tak zwanej ,polityki równego dystansu" wobec ChRL i Związku Radzieckiego, zmieniało też konfigurację polityczną na Dalekim Wschodzie. Moskwa obawiała sie wprawdzie, by zbliżenie amerykańsko-chińskie i japońsko-chińskie nie doprowadziło do stworzenia wspólnego frontu tych trzech mocarstw przeciwko niej, jednakże wobec niepowodzeń dotychczasowej polityki drobnych ustępstw wobec Japonii, nie tylko usztywniła swe stanowisko, ale nawet zaczęła ,grozić kijem". Stosunki radziecko-japońskie uległy dalszemu ochłodzeniu. Dało się to zauważyć wyraźnie podczas rokowań dotyczących rybołówstwa w radzieckiej 200-milowej strefie ekonomicznej. Nastąpiła też znaczna aktywizacja radzieckich sił zbroj nych w tym regionie, szczególnie na terytoriach spornych. Rozbudowywano tam potencjał militarny, głównie na wyspach Etorofu i Kunaszir, a flota radziecka coraz szerzej penetrowała wody zachodniego Pacyfiku. W nocie werbalnej skierowanej 23 sierpnia 1978 r. do japońskiego Ministerstwa Spraw Zagranicznych, Zinowiew, radziecki charge d'affaires w Tokio, stwierdził, między innymi, że „Związek Radziecki podejmie kroki, jakie uzna za stosowne w celu obrony swego terytorium" ${ }^{59}$

$\mathrm{Na}$ ochłodzenie stosunków japońsko-radzieckich dodatkowo wpłynęło kilka czynników: wprowadzenie wojsk radzieckich do Afganistanu w grudniu 1979 r., ogłoszenie stanu wojennego w Polsce i zestrzelenie przez radziecka obronę przeciwlotniczą samolotu pasażerskiego KAL, który zboczywszy $\mathrm{z}$ trasy wtargnął $\mathrm{w}$ radziecką przestrzeń powietrzną. Pod naciskiem Stanów Zjednoczonych Japonia przyłączyła się wtedy do sankcji wobec Moskwy. W rezultacie w latach 1978-1982 nastąpiło ograniczenie kontaktów politycznych na wyższym szczeblu, zahamowanie współpracy gospodarczej, przerwanie rozmów o współpracy kulturalnej, a Japonia przyłączyła się do bojkotu olimpiady w Moskwie.

\section{Próby odbudowy współpracy}

Stopniowe przywracanie kontaktów na wysokim szczeblu rozpoczęło się dopiero w drugiej połowie 1984 r. (w październiku spotkanie ministrów

\footnotetext{
${ }^{58}$ Tekst traktatu w: Japan Quarterly, vol. XXV, nr 4 z 1978, s. 50-51.
}

${ }^{59}$ KCA 1978, s. 29038 spraw zagranicznych A. Gromyki i S. Abe na XXXIX sesji ONZ w Nowym Jorku, w listopadzie spotkanie premiera Tichonowa i Nakasone w New Delhi). Towarzyszyło temu ożywienie kontaktów gospodarczych, zwłaszcza w strefie przygranicznej.

Po dojściu do władzy Michaiła Gorbaczowa (marzec 1985 r.) dało się zauważyć wyraźne zmiany w polityce Moskwy wobec Japonii, chociaż nie od razu zaczęto mówić o możliwości rozwiązania problemu terytorialnego. W styczniu 1986 r. minister spraw zagranicznych Związku Radzieckiego Eduard Szewardnadze złożył (pierwszą od 10 lat oficjalną) wizyte $\mathrm{w}$ Tokio i nie odmówił umieszczenia w programie rozmów kwestii terytorialnych. Jednakże kiedy problemy te zaczęto omawiać, powtórzył stanowisko prezentowane $\mathrm{w}$ ostatnich latach, że spór został już rozwiązany, a problem nie istnieje. Rozmowy skończyły sie postanowieniem kontynuowania negocjacji $\mathrm{w}$ sprawie zawarcia traktatu pokojowego na bazie formuły Breżniew Tanaka z 1973 r.

W maju 1986 r. Moskwe odwiedził japoński minister spraw zagranicznych Shintaro Abe. Obie wizyty doprowadziły do poprawy klimatu politycznego w stosunkach dwustronnych, jednakże w kwestii terytorialnej każda ze stron broniła dotychczasowego stanowiska. Widoczne to było, np. podczas konsultacji wiceministrów spraw zagranicznych Michaiła Kapicy i Shinichi Yanai w listopadzie 1986 r. W rezultacie stało się jasne, że choć istnieje wiele problemów utrudniających rozwój stosunków Japonii i ZSRR, przeszkoda zasadnicza sa japońskie roszczenia terytorialne. Japonia uzależniała bowiem zgodę na pełną normalizację stosunków dwustronnych i podpisanie traktatu pokojowego od całkowitego rozwiązania problemu terytorialnego.

Wycofywanie wojsk radzieckich z Afganistanu w 1988 r., normalizacja stosunków radziecko-chińskich, zakończenie „zimnej wojny" i przeobrażenia, jakie zachodziły w samym Zwiazku Radzieckim w wyniku „pierestrojki" prowadzonej przez Michaiła Gorbaczowa, wpłynęły na odczuwalną poprawę stosunków z Japonią.

W czerwcu 1988 r. w Moskwie odbyły się radziecko-japońskie konsultacje z udziałem wiceministrów spraw zagranicznych Igora Rogaczewa Takakazu Kuriyamy, Strona radziecka po raz pierwszy w historii japońsko-radzieckich negocjacji dyplomatycznych zaproponowała „zrewidowanie linii granicznej" między obu państwami. Zdaniem moskiewskiego korespondenta japońskiej gazety The Mainichi Shimbun z 29 czerwca tego roku (powołującego się na przedstawiciela japońskiego MZS), Związek Radziecki zastosował „nowa koncepcje retoryczna", by nie traktować sprawy „Terytoriów Północnych" jako „kwestii terytorialnej". Zdaniem tegoż korespondenta ta nowa formuła pozwoliłaby przełamać impas 
w sprawie „Terytoriów Północnych", gdyż Związek Radziecki wolałby raczej ponownie wytyczyć granicę państwową między obu krajami niż rozpatrywać konkretne roszczenia terytorialne. W ten sposób bowiem uniknąłby stawiania podobnych kwestii przez inne państwa, np. przez Chiny i niektóre państwa europejskie. „Nowa retoryka" radziecka pozwoliłaby zatem doprowadzić do zwrotu wysp Habomai i Szikotan, nie wywołując roszczeń ze strony innych państw. Wówczas jednak Tokio tę propozycję odrzuciło.

Koniec prezydentury Gorbaczowa już wyraźnie wskazuje, że w polityce zagranicznej Związku Radzieckiego zwyciężył kurs „nowego myślenia". Moskwa zaczęła zmieniać postawę wobec wielu problemów. Dotyczyło to także podejścia do kwestii terytorialnej w stosunkach z Japonią. Jeszcze na początku 1990 r. Gorbaczow nie chciał prowadzić dyskusji na ten temat, twierdząc, że takiego problemu nie ma, ale już w czerwcu tegoż roku, w trakcie szczytu Gorbaczow-Bush, nieoficjalnie mówił o możliwym „Zwrocie terytoriów północnych" w zamian za pomoc gospodarczą ze strony Japoniii ${ }^{60}$.

Istnienie „problemu terytorialnego" radziecki prezydent potwierdził podczas wizyty w Tokio. We wspólnym oświadczeniu opublikowanym 18 kwietnia 1991 r. po raz pierwszy od lat mówi się o "problemie przynależności wysp Habomai, wyspy Szikotan, wyspy Kunaszir i wyspy Etorofu"61. Po powrocie z Tokio, na sesji Rady Najwyższej Gorbaczow stwierdził, że przez całe lata udawano, Że „taki problem w ogóle nie istnieje" ${ }^{62}$

W stosunkach między obu krajami zaczął się rysować przełom, a wśród Japończyków ożywiły się nadzieje na rzeczową dyskusję tego problemu. Wywołało to jednak oburzenie Borysa Jelcyna, prezydenta Rosji. Był on niezadowolony, że o terytorium należącym do Rosji decyduje się bez jego udziału. Wyraził opinię, iż ,jakakolwiek próba zmiany granic republiki musi być zatwierdzona $w$ powszechnym referendum. Nawet jeśli Związek Radziecki zgodzi się zwrócić te wyspy Japonii, Rosja może postawić weto"63. Protest ten jednak służył głównie rozgrywce z Gorbaczowem, bowiem Borys Jelcyn planując swą wizytę w Tokio we wrześniu 1992 r. gotów był zakomunikować stronie japońskiej możliwość rozwiązania „problemu terytorialnego", na podstawie „Wspólnej deklaracji" z 19 X 1956 r. To jest godził się zwrócić Japonii wyspy Habomai i Szikotan po podpisaniu trak-

\footnotetext{
${ }^{60}$ Mainichi Daily News z dnia 7 czerwca 1990 n

${ }^{61}$ Niezawisimaja Gazieta z 29 stycznia $1999 \mathrm{r}$.

62 j.w.

${ }^{63}$ Za agencją INTAR-TASS, 1 września 1992 r.
}

tatu pokojowego. Niektóre kręgi polityczne skłonne były nawet oddać Japonii wszystkie sporne wyspy ${ }^{64}$, co wywołało protesty Dumy.

Utworzono w niej grupę deputowanych do spraw spornych terytoriów. Do protestów przyłączyli się też wojskowi, zarówno ci, których w $1945 \mathrm{r}$ przekonywano, że walczą o „dawne terytoria rosyjskie", jak też pełniący aktualnie służbę na spornych wyspach. Wspierali ich również mieszkańcy wysp. Utworzono wiele komitetów obronnych, które zapowiadały walkę z Japończykami, jeśli przejęliby oni te terytoria. Niezwykle głośno protestował gubernator Sachalinu Walentin Fiodorow. Nazwał on polityków z Moskwy „sprzedawczykami rosyjskiej ziemi" i zapowiedział, że oskarży Jelcyna przed trybunałem konstytucyjnym, jeśli ten odda Japonii Południowe Kuryle ${ }^{65}$. Miał on silne poparcie kręgów wojskowych i zindoktrynowanej ludności tych-wysp. Jest to głównie element napływowy, często wymieniany tak jak wymieniane ekipy wojskowych. Stałych mieszkańców, to jest takich, którzy mieszkają tu od 1945 roku, jest niewielu. Mieszkańcy tych wysp byli przez całe lata przekonywani, że armia radziecka wyzwalała rosyjskie terytoria — „Sachalin i Wyspy Kurylskie" spod japońskiego panowania, że wyspy Kurylskie „zawsze były i powinny pozostać nasze" (to jest rosyjskie) ${ }^{66}$.

Tę historyczną nieprawdę radzieccy historycy i politolodzy powtarzal nieustannie za czasów komunizmu, a w rezultacie utrwalane przez lata kłamstwa stały się dziś ,prawdą" trudną do odkłamania. Czołowy radziecki badacz stosunków z Japonią, L. N. Kutakow w swojej książce Wnieszniaja politika i dipłomacija Japonii (Moskwa 1964,) na stronie 314 pisze, że ,w lutym 1945 roku w Jałcie rządy Stanów Zjednoczonych i Wielkiej Brytanii uznały przywrócenie historycznych praw państwa radzieckiego do Wysp Kurylskich i Sachalinu Południowego". Ciagle jeszcze, mimo upływu 54 lat od zakończenia II wojny i w zupełnie nowej sytuacji politycznej, nie tylko na rosyjskim Dalekim Wschodzie, ale i w Rosji centralnej, czołowe dzienniki piszą o Wyspach Kurylskich jako „odwiecznych ziemiach rosyjskich"67, a stacjonujący na nich młodzi żołnierze (przybyli tu najczęściej z części europejskiej) mówią, że gotowi są nawet walczyć z Japończykami o nie.

${ }^{64}$ „Kakoj dogowor nużen Rossii i Japonii” w: „Niezawisimaja Gazieta" z 18 listopada $1998 \mathrm{n}$

${ }^{65}$ W Fiodorow - „Słowo gubernatora. Rjadom s Japoniej", w: „Gubernskie wiedomosti" z dnia 5 września $1992 \mathrm{r}$.

66 „Kurily russkaja zemla", „Ja - protiw!", w: j.w.

${ }_{67}$ „Niezawisimaja Gazieta" z dnia 27 października 1998 r. Autor artykułu - M. A.

Wajsfeld pisze: ,wojska radzieckie... wyzwoliły Południowy Sachalin i wszystkie Kuryle". 
Atmosfera wokół zapowiedzianej na jesień 1992 r. wizyty Borysa Jelcyna w Japonii była tak niesprzyjająca, że Jelcyn ją odwołał pod pretekstem grypy. Doszło do niej dopiero w październiku 1993 r. Podpisano wówczas porozumienie zwane Deklaracją Tokijską. Przewidywało ono przeprowadzenie „poważnych rozmów na temat przynależności wysp Etorofu, Kunaszir, Szikotan i Habomai". Omawiano tę kwestię także w listopadzie 1998 r., podczas 'spotkania Jelcyna z premierem Japonii Keizo Obuchi w Moskwie. W komunikacie końcowym z tego spotkania spornych wysp nie nazywa się już „terytorium Federacji Rosyjskiej"68.

Takie podejście do kwestii terytorialnej na najwyższych szczeblach władzy, wywołało niezadowolenie różnych kół politycznych w Moskwie. Większość tamtejszych polityków wyznaje bowiem zasadę „terytorialnej integralności Rosji", co wyklucza - ich zdaniem — „dyskusję nad przynależnością Kuryli Południowych" ${ }^{69}$.

Obie strony wielokrotnie podkreślały, że rozwiązanie tego problemu pozwoli na pełna normalizację stosunków rosyjsko-japońskich. Jednak od deklaracji w Krasnojarsku, zapowiadajacej podpisanie traktatu pokojowego do 2000 roku, rozmowy pokojowe utknęły w ślepym zaułku. Podczas spotkania Borysa Jelcyna z premierem Hashimoto w Kanawa, w kwietniu 1998 r., rosyjski prezydent wystapił ponownie z propozycja zawarcia „układu o przyjaźni", który z góry wykluczał rozwiązanie kwestii terytorialnej. Nadziei na to nie dały także rozmowy ministra spraw zagranicznych Rosji Igora Iwanowa w Tokio w dniach 20-23 lutego 1999 r. Jak podawała prasa japońska, powołując się na dobrze poinformowane źródła dyplomatyczne, Iwanow miał wówczas powiedzieć, ,że Moskwa nie zrezygnuje ze spornych wysp na rzecz Japonii".

Nic nie wskazuje też na to, by Japonia miała zamiar wycofać się ze swych żądań. Jak stwierdził Nagao Hyodo, ambasador Japonii w Polsce, w wykładzie wygłoszonym w Towarzystwie Azji i Pacyfiku w marcu 1997 r., Japonia nigdy nie zmieni stanowiska w sprawie „terytoriów północnych" i zawsze bedzie o nich Rosji przypominać. Nie może ona bowiem zaakceptować istniejącego stanu rzeczy ze względu na odczucia ludności, zasady sprawiedliwości i dumę narodową.

Dla Japonii jest to „sprawa narodowa", a odzyskanie „bezprawnie zagarniętych ziem" stanowi hasło sztandarowe polityki zagranicznej Japonii. Podczas gdy rząd zgłasza roszczenia tylko do czterech „wysp pó1nocnych", większość partii opozycyjnych domaga się zwrotu całego łańcucha Wysp Kurylskich, a także południowej części Sachalinu.

${ }^{68}$ „Moskowskaja deklaracja" — „Niezawisimaja Gazieta" z 2 grudnia 1998 r

69 "My nie dadim potierjat Rossiju" „Niezawisimaja Gazieta" z 16 stycznia 1999 r.

\section{9- Warianty rozwiązania sporu}

Rosja i Japonia od lat poszukuja najlepszej formuły rozwiązania sporu. Żaden jednak z jej wariantów nie wydaje się satysfakcjonować w pełni obu stron. W ostatnich latach rozpatrywano, m.in. następujące koncepcje:

a) Formułe „kondominium", która przewiduje wspólną władzę na czterech spornych wyspach, w tym poprzez tworzenie joint ventures,

(kierowanych przez Rosjan) i promowanie wspólnego eksportu oraz turystyki (utworzenie na Kunaszir parku narodowego otwartego dla turystów z całego świata). Kiedy Jewgienij Primakow, minister spraw zagranicznych Rosji, podczas oficjalnej wizyty w Tokio, w listopadzie 1996 r. złożył propozycję współpracy rosyjsko-japońskiej nad rozwojem Wysp Kurylskich, Japonia zaakceptowała tę ideę zapewniając, iż gotowa jest udzielić Rosji $500 \mathrm{mln}$ dol. kredytu na ten cel.

b) Formułe „2 + alfa", co oznacza zwrot czterech spornych wysp w dwóch etapach. Ta „formuła dwustopniowa" przewidywała, że Rosja zwróci Japonii najpierw wyspy Habomai i Szikotan (zgodnie ze Wspólną Deklaracją z X 1956 r.) i uzna jednocześnie formalna suwerenność Japonii nad całym terytorium spornym. Następnie podpisany zostanie traktat pokojowy, ale Rosja bedzie nadal sprawowała faktyczny zarząd nad Etorofu i Kunaszir, które przekaże Japonii dopiero po rozwiązaniu wszystkich problemów, między innymi związanych $\mathrm{z}$ określeniem sytuacji mieszkańców wysp, czy też likwidacją wszystkich baz rosyj$\mathrm{skich}^{70}$. Japonia skłonna jest udzielić pomocy finansowej na przeprowadzenie tych operacji.

c) Utworzenie na czterech wyspach ,wolnej strefy ekonomicznej".

d) Wycofanie $\mathrm{z}$ nich wojsk rosyjskich i ustanowienie nad nimi powiernictwa ONZ.

e) Sprzedaż Japonii tych wysp za 20-30 mld dol., mimo że z ekonomicznego punktu widzenia wyspy te nie mają dla Japonii większego znaczenia; „niemal zero" jak oceniała ich wartość gospodarczą The Daily Yomiuri z dnia 22 czerwca 1990 r. Zdaniem japońskiej gazety, stopień degradacji tamtejszego środowiska naturalnego jest tak wielki, że potrzeba dziesiątków lat i ogromnych pieniędzy japońskich podatników, by przeprowadzić całkowita rekultywację terenu. Przy tym wyspy te nie są atrakcyjne ani dla rolników, ani dla biznesmenów japońskich. Zimny, arktyczny klimat zawsze stwarzał władzom Japonii kłopoty

\footnotetext{
${ }^{70}$ „Scenariusz dla Południowych Kuryli” „Niezawisimaja Gazieta" z 1 lipca 1999 r.
} 
z osadnictwem na tych terenach. Próba osadnictwa na Sachalinie pokazała, że Japończycy nie znoszą zimnego klimatu. Z tego samego powodu niewielu rolników osiedlało się w Mandżurii czy Korei. Patrząc na rozmieszczenie osadników na Wyspach Kurylskich do 1945 r. wyraźnie widać, że 90\% wszystkich mieszkańców archipelagu kurylskiego mieszkało na czterech wyspach, których zwrotu domaga się Japonia. Klimat na nich był tam jeszcze akceptowalny dla ciepłolubnych Japończyków.

f) Wydzierżawienia wysp Japończykom na 99 lat.

g) Wyznaczenie granicy między Etorofu i Urup, to jest powrót do granicy z 1855 r., uznanie tych wysp za terytoria japońskie, ale pozostawienie ich pod administracją Rosji przez pewien określony czas.

\section{Pytania o przyszłość}

Od lat stosunki między Moskwą i Tokio są chłodne. Zmienić je może tylko pełna normalizacja, to jest podpisanie traktatu pokojowego. Przeszkodą jest jednak nierozwiązany dotąd spór terytorialny. W ostatnim czasie dało się zauważyć, że obie strony starają się tę sprawę minimalizować. Wynika to w dużej mierze $\mathrm{z}$ perspektyw rozwoju współpracy w zagospodarowaniu rejonów Syberii i rosyjskiego Dalekiego Wschodu ${ }^{71}$ Japonia, która do tej pory uzależniała wysokość pomocy ekonomicznej dla Rosji od postępów w rozwiązaniu „problemu terytorialnego", zmienia w tej kwestii swoje stanowisko ${ }^{72}$. Z W wpowiedzi, cytowanego na początku artykułu przedstawiciela rządu japońskiego wynika, że Japonia gotowa jest nawet podpisać traktat pokojowy $\mathrm{z}$ Rosją przed rozstrzygnięciem formuły odzyskania spornych terytoriów, ale pod warunkiem zapisu w traktacie, że należą one do Japonii. Zdaniem owego przedstawiciela, logiczne było-

${ }^{71}$ Wymiana rosyjsko-japońska w ostatnich latach regularnie wzrasta. W 1997 Ł wynosiła 5 mld USD. Jej wartość znacznie wzrosła po wejściu w życie tzw. projektu Sachalin-2. Dotyczy on wydobycia ropy naftowej z szelfu sachalińskiego. W związku z realizacją tego projektu utworzono „Sakhalin Energy Investment Company Ltd.", w skład której wchodzą, obok amerykańskiech i holenderskich, także japońskie firmy: Mitsui (25\%) i Mitsubishi $(12,5 \%)$.

${ }^{72}$ W kwietniu 1998 Ł Japonia przyznała Rosji (po spotkaniu Hashimoto - Jelcynem) kredyt $\mathrm{w}$ wysokości $1,5 \mathrm{mld}$ USD, na realizację reform gospodarczych. Po przekazaniu ( $\mathrm{w}$ lipcu) pierwszej transzy kredytu, w wysokości $400 \mathrm{mln}$ USD, nastąpiło jego zamrożenie częściowo związanie z kryzysem, który nastąpił w Rosji w sierpniu 1998 r. oraz brakiem postępów w rozwiązaniu „problemu terytorialnego". Jego odmrożenie nastąpiło po wejściu wżycie projektu „Sachalin-2". by rozstrzygnięcie najpierw kwestii terytorialnej, a dopiero potem podpisanie porozumienia pokojowego, lecz z uwagi na interesy Japonii i Rosji, praktyczne aspekty kwestii terytorialnej można również dyskutować po zawarciu traktatu pokojowego, gdy tylko ustali się zasady gospodarowania na spornych wyspach.

Śledząc trwający ponad pół wieku japońsko-rosyjski spór nasuwa się pytanie: czy Moskwa jest rzeczywiście zainteresowana w jego rozwiązaniu? Po rozpadzie Związku Radzieckiego w 1991 r. i utracie dostępu do większości portów czarnomorskich oraz bałtyckich, jak też wraz z szybkim rozwojem gospodarczym regionu Pacyfiku, Wyspy Kurylskie nabrały nowego znaczenia. Ustalenie granicy między Etorofu i Urup, to jest powrót do granicy z 1855 r., ponownie stworzyłyby problem wyjścia na Pacyfik flocie rosyjskiej. Z punktu widzenia rosyjskiej gospodarki zasobami rybnymi również niekorzystny jest wariant przewidujący przekazanie Japonii całych Kuryli Południowych. Obecnie Moskwa określa rybakom japońskim kwoty połowowe na łowiskach w rejonie spornych wysp. Zmiana ich przynależności musiałaby spowodować sytuację odwrotną.

W Rosji brak odpowiedniego klimatu, by ów spór rozwiązać i dokonać jakichś cesji terytorialnych. Istnieją ponadto poważne rozbieżności między stanowiskiem władz centralnych — gotowych znaleźć rozwiązanie, lokalnych - uważających oddanie wysp za zdradę interesów narodowych, a wreszcie stanowiskiem mieszkańców tych wysp, którzy z jednej strony nie chca powrotu wysp do Japonii, z drugiej — chętnie witają każdy rodzaj współpracy z nią, bo ta w widoczny sposób poprawia ich warunki życiowe.

W warunkach kryzysu wewnętrznego w samej Rosji (ideowego i politycznogospodarczego), jak też konfliktów etnicznych na Kaukazie oraz w Azji Środkowej i rozpadu Wspólnoty Niepodległych Państw, problem sporu o Kuryle Południowe ma wprawdzie dla Moskwy niewielkie znaczenie praktyczne, ale duże - symboliczne. Utrata części terenów dawnego Związku Radzieckiego (i Cesarstwa Rosyjskiego) na rzecz narodów uzyskujących niepodległość jest bolesna, ale łatwiej akceptowalna. Tu jednak chodzi o przekazanie wysp innemu mocarstwu, i to takiemu, $\mathrm{z}$ którym toczono w przeszłości krwawe wojny, na trwałe zapisane w świadomości narodowej. Oddawanie Japonii jakichkolwiek terytoriów, choćby najmniej znaczących, budzi ogromne emocje społeczne.

Nie bez znaczenia są również wyobrażenia „klasy politycznej" o priorytetach rosyjskiej polityki zagranicznej. Wbrew pozorom, i propagandowemu eksponowaniu niekiedy znaczenia konfliktów z Japonią, zajmowała ona zawsze marginalną pozycję w polityce zagranicznej Rosji, zorientowanej głównie na Europę. Również dla Japonii stosunki ze Związkiem Radzieckim i Rosją nie miały zbyt dużego znaczenia. Wprawdzie od połowy 


\section{E. Potocka}

XIX W. oba państwa rywalizowały ze sobą o strefy wpływów na Dalekim Wschodzie, jednakże wysuwało to stosunki z partnerem na czoło zainteresowań elit tylko w okresach najostrzejszych napięć i starć zbrojnych. Obecnie na liście priorytetów polityki zagranicznej Rosji Japonia zajmuje dopiero drugie miejsce, po Chinach. Dla Japonii Rosja też jest partnerem mało znaczącym, i w jej regionie plasuje się dopiero po Chinach i obu państwach koreańskich. Stąd przez lata oba państwa nie podejmowały większych wysiłków dyplomatycznych w celu poprawy wzajemnych stosunków.

Śledząc rozwój ich wzajemnych stosunków politycznych po 1956 r., rosyjskie działania można by nazwać „dyplomacją ruchów pozornych". Większość wysuwanych $\mathrm{w}$ ostatnich latach propozycji rozwiązania problemu terytorialnego miała wyraźnie charakter koniunkturalny. Rosja przez lata łączyła problem Kuryli Południowych z oczekiwaniami konkretnych świadczeń gospodarczych ze strony Japonii. Liczyła na udział Japonii w zagospodarowaniu terenów Syberii i rosyjskiego Dalekiego Wschodu. A trzeba pamiętać, że znajdowały się one na marginesie zainteresowań gospodarczych elit moskiewskich, również w czasach świetności Związku Radzieckiego, mimo ich bogatych zasobów surowcowych. Po wprowadzeniu gospodarki rynkowej przestano je zaś subsydiować centralnie. Stwarza to Japonii, z uwagi na bliskość, ogromne możliwości w zagospodarowaniu i korzystaniu $\mathrm{z}$ bogactw tych rejonów - tarcicy, węgla kamiennego, ropy naftowej, gazu ziemnego, itd.

Japońsko-rosyjski spór terytorialny należy rozpatrywać na tle sytuacji geopolitycznej w tym rejonie Azji. W latach ostatnich na Dalekim Wschodzie znikła większość czynników, utrudniających poprzednio porozumienie Rosji z Japonią. Zakończenie zimnej wojny i rozpad Związku Radzieckiego spowodowały, że sojusz Japonii ze Stanami Zjednoczonymi nie stanowi już zagrożenia dla interesów Rosji na jej wschodnich rubieżach. Podobnie dla USA ewentualne porozumienie Japonii z Rosją nie budzi szczególnych obaw. Obecne stosunki Moskwy z Pekinem rozwijaja się pomyślnie, a przecież to właśnie Chiny przez lata popierały najgoręcej japońskie roszczenia terytorialne.

Nie podpisanie dotychczas traktatu pokojowego Rosji z Japonią kładzie się cieniem na pozycję polityczną obu państw w rejonie Azji-Pacyfiku. Brak pełnej normalizacji stosunków i wytyczenia granicy między obu państwami stanowi istotną przeszkodę nie tylko w dwustronnej współpracy politycznej i gospodarczej, ale uniemożliwia utworzenie też jakiegoś wielostronnego systemu bezpieczeństwa regionalnego, z udziałem USA, Japonii, Korei, ChRL i Rosji.

Rosja uważała się zawsze nie tylko za mocarstwo europejskie, ale i azjatyckie. Jednak jej rola w regionie, po rozpadzie Związku Radzieckiego i utracie sojuszników w Azji, jest drugorzędna. Brak pełnej normalizacji stosunków z Japonia dodatkowo osłabia tam jej pozycje i zmniejsza wiarygodność jej działań. W lipcu 1986 r. Michaił Gorbaczow wystąpił z inicjatywą utworzenia systemu zbiorowego bezpieczeństwa, przypominającego w założeniach system KBWE w Europie (proponowano to już wcześniej, ale $\mathrm{w}$ erze konfrontacji miało to przede wszystkim charakter propagandowy). Nie jest jednak możliwe utworzenie jakiegokolwiek regionalnego systemu bezpieczeństwa, jeśli między państwami danego regionu istnieją spory terytorialne.

Podejście Rosji do regionu Azji-Pacyfiku jednakże zmienia się. Chciałaby ona zająć w rozwijającej się tam współpracy znaczące miejsce. Czy istnieją jednak w Moskwie siły polityczne zdolne podjąć decyzję o „poświęceniu" terytoriów spornych dla długofalowych celów politycznych? W Rosji nie ma obecnie przywódcy o tak wielkim autorytecie politycznym, by mógł on nie tylko podjąć decyzję o zwrocie Japonii wysp Etorofu i Kunaszir, ale i zrealizować ją. Dyskusje na temat sporu terytorialnego sa już jednak tak zaawansowane, że jego rozwiązanie wydaje się tylko kwestią czasu. Zależeć to będzie od pojawienia się w Moskwie polityków nowej generacji, wolnych od wojennych obciążeń i resentymentów, którzy uznają, że zakończenie sporu leży po prostu w interesie Rosji. 